\title{
Penurunan Fraksi Ejeksi Ventrikel Kiri dalam Enam Bulan Meningkatkan Faktor Resiko Gangguan Kognitif Penderita Gagal Jantung Sistolik
}

\author{
Risky Ilona Saputra, I Made Oka Adnyana, AAA Putri Laksmidewi, Anna Marita Gelgel, I Putu Eka Widyadharma
}

\begin{abstract}
Abstrak
Gangguan kognitif sering dijumpai pada penderita gagal jantung sistolik dan tidak terdeteksi sejak awal. Hal ini memperburuk kondisi dan luaran klinis penderita. Penelitian ini bertujuan untuk mengetahui adanya peningkatan risiko terjadinya gangguan kognitif pada penderita gagal jantung sistolik dengan penurunan fraksi ejeksi ventrikel kiri dalam enam bulan. Metode penelitian ini adalah kontrol kasus, di Poli Jantung dan Poli Saraf RSUP Sanglah, Denpasar, periode Oktober 2018 hingga Desember 2018. Analisis data dilakukan dengan SPSS versi 22. Penelitian ini menggunakan 76 subjek, dengan rerata usia 50,3 \pm 4,5 tahun. Karakteristik yang lebih dominan dijumpai pada jenis kelamin laki-laki 44 orang (57,9\%), pendidikan $\geq 12$ tahun 40 orang $(52,6 \%)$, dan pekerjaan formal 40 orang (52,6\%) Dari hasil analisis statistik didapatkan persentase penurunan fungsi kognitif pada kelompok kasus sebesar $89,5 \%$ sedangkan pada kelompok kontrol didapatkan 13,2\%. Analisis bivariat dengan Chi-square, didapatkan nilai OR=56,1; IK 95\% 13,844-227,338; p<0,001. Pada analisis multivariat didapatkan penurunan FEVK dalam enam bulan merupakan faktor risiko yang kuat, memiliki risiko mengalami gangguan kognitif pada penderita gagal jantung sistolik dengan adjusted $\mathrm{OR}=23,1$, setelah mengendalikan jenis kelamin, pendidikan dan pekerjaan, OR=23,1; IK 95\% 4,7114,$03 ; p<0,001$. Penelitian ini menyimpulkan bahwa penurunan FEVK dalam enam bulan sebagai faktor risiko gangguan kognitif penderita gagal jantung sistolik. Penulis menyarankan para klinisi perlu melakukan pemeriksaan fungsi kognitif pada penderita gagal jantung sistolik .
\end{abstract}

Kata kunci: gangguan kognitif, penurunan FEVK, gagal jantung sistolik

\begin{abstract}
Cognitive impairment was common finding in systolic heart failure patient and also not early detected. it produced negative effect and worsening outcome. This study aims to determine increased of risk cognitive function impairment in systolic heart failure patient with decreased left ventricular ejection fraction in six months. The study used a case-control design, in Cardiologi and Neurologi Clinic Sanglah Hospital, Denpasar, from October 2018 to December 2018. Data was analized using SPSS version 22. A total of 76 subjects were recruited. The mean age was $50,3 \pm 4,5 y e a r s$, more dominant in male sex ( $n=44,57,9 \%)$, study $\geq 12$ years $(n=40,52,6 \%)$, formal occupation ( $n=40$, $52,6 \%$ ). From the statistical analysis it was found that the percentase of cognitive impairment in case group $89,5 \%$ and $13,2 \%$ in control group. Bivariate analysis with Chi-square (OR=56,1: CI95\%=13,844-227,338: $p<0,001)$. There was a significant association between increased of cognitive function impairment and decreased left ventricular ejection fraction in six months in systolic heart failure patient. From the multivariate analysis, it was found that the decreased left ventricular ejection fraction in six months, which allowed a 23 times greater risk cognitive function impairment in systolic heart failure patients ( adjusted $O R=23,1: C 195 \%=4,7-114,03: p<0,001$ ). We conclude that increased cognitive function impairment twenty four folds in systolic heart failure patient with decreased left ventricular ejection fraction in six months in Sanglah General Hospital statistically significant. The author suggest that clinicians need to consider doing congnitive function examination in in systolic heart failure patient.
\end{abstract}

Keywords: cognitive function, decreased left ventricular ejection fraction, systolic heart failure

Affiliasi penulis : Fakultas Kedokteran Universitas Udayana, Denpasar, Bali

Korespondensi : okaadnyanadrsps@yahoo.com Telp: 0817347697

Pendahuluan

Gangguan Fungsi Kognitif (GFK) mempunyai prevalensi yang semakin meningkat di dunia. Gangguan fungsi kognitif sering dijumpai pada penderita gagal jantung dan tidak terdeteksi sejak awal. Tingginya prevalensi GFK pada penderita gagal jantung memberikan dampak negatif terhadap luaran klinis serta memperburuk kondisi penderita gagal jantung. Pada pasien usia tua dengan gagal jantung, disfungsi kognitif dikaitkan dengan peningkatan risiko kematian lima kali lipat. ${ }^{1}$ Kecacatan menyebabkan peningkatan konsumsi sumber daya pada penderita gagal jantung dan merupakan penyakit medis yang paling mahal di Amerika Serikat. Gagal jantung menjadi masalah kesehatan utama pada $1-2 \%$ dari populasi orang dewasa di negara berkembang, terdapat peningkatan prevalensi $6-10 \%$ pada usia di 
atas 65 tahun dan $\geq 10 \%$ pada usia diatas 70 tahun. $^{2}$ Gagal jantung dikaitkan dengan GFK yang dapat meningkatan mortalitas, morbiditas, lama perawatan rumah sakit, dan berkurangnya kualitas hidup.Gangguan fungsi kognitif adalah salah satu penyakit kronis yang paling sering terjadi pada orang tua dengan gagal jantung. Kejadiannya bervariasi $25 \%$ sampai $70 \%-80 \%$ tergantung pada karakteristik sampel, dan juga desain penelitian yang digunakan. ${ }^{3}$

Penderita gagal jantung mengalami gangguan di beberapa area serebral terutama gangguan kognitif, disebabkan oleh hipoperfusi serebral akibat perubahan curah jantung dan reaktivitas serebrovaskular, hipotensi arteri, produksi sitokin proinflamasi. ${ }^{4}$ Sekitar $30-80 \%$ penderita gagal jantung pada usia lebih dari 75 tahun yang diikuti selama 5 tahun mengalami gangguan kognitif, dengan risiko relatif penurunan kognitif 1,80 (interval kepercayaan $95 \%, 1,02-3,27) .^{5}$

Gangguan fungsi kognitif dapat mengganggu proses pengambilan keputusan yang aktif untuk menjaga kesehatan, menghadapi penyakit dan perubahan kepribadian. Gangguan fungsi kognitif meningkatkan angka kematian, tingginya perawatan rumah sakit dan gangguan fungsional. Berkurangnya fraksi ejeksi ventrikel kiri (FEVK) dapat mempengaruhi perfusi serebral dan berkontribusi pada cedera otak klinis. Pada pasien kardiomiopati berat, FEVK menyebabkan penuaan otak abnormal, gangguan kognitif, kelainan struktur neuroanatomi dan peningkatan risiko penyakit Alzheimer. ${ }^{6}$

Pada penelitian Cermakova, tidak terdapat hubungan antara tipe demensia dan tipe gagal jantung. Tingkat mortalitas pasien dengan gagal jantung dan demensia adalah 24\% dalam 1 tahun, namun peningkatan mortalitas tidak berhubungan dengan tipe dementia dan gagal jantung. ${ }^{7}$ Pada penelitian Hoth dilaporkan gangguan kognitif pada penderita gagal jantung usia tua, namun hasilnya tidak konsisten. Pada pasien geriatri terdapat korelasi gangguan kognitif dengan penurunan FEVK dibawah $30 \%$ dengan 53\% Mini Mental State Examination (MMSE) kurang dari 24 terutama gangguan atensi. ${ }^{8}$ Penelitian lainnya terdapat perbedaan pendapat misalnya, pada studi Zuccala, peran FEVK diteliti pada usia dewasa tua dengan sampel kecil (rerata usia 76.6) yang menderita gagal jantung kronik (NYHA kelas III, FEVK 44\%) didapatkan hubungan tidak bermakna antara FEVK dan MMSE. ${ }^{9}$ Penelitian Festa, pada 207 pasien dengan gagal jantung (rentang usia 17-72 tahun), didapatkan korelasi FEVK terhadap usia, yaitu kurang dari 63 tahun tidak ada penurunan fungsi memori terkait dengan FEVK, sedangkan pada usia lebih dari 63 tahun terdapat penurunan signifikan memori (terutama verbal delayed recall dan rekognisi) dengan FEVK $\leq 30 \%(P<0,02) .{ }^{10}$ Hurk menemukan penderita gagal jantung yang dirawat jalan juga penderita gagal jantung dengan eksaserbasi yang dirawat (rerata usia 55-70 tahun dan variabel FEVK $25.7 \%$ dan $63 \%$ ), tidak ada hubungan antara fraksi ejeksi dan fungsi kognisi yang dinilai dengan tes global dan skala spesifik (Boston Naming Test, Trail Making Test Part B-Part A, Hooper Visual Organization Test). ${ }^{11}$

Penelitian ini bertujuan untuk melihat apakah penurunan FEVK dalam enam bulan merupakan faktor risiko GFK pada penderita gagal jantung sistolik (GJS).

\section{Metode}

Penelitian ini merupakan studi observasional analitik dengan rancangan case control, pada penderita penyakit GJS di poliklinik saraf dan poliklinik jantung Rumah Sakit Umum Pusat Sanglah, Denpasar, mulai bulan Oktober 2018 hingga bulan Desember 2018. Besar sampel yang dibutuhkan dihitung menurut rumus untuk jenis penelitian analitik kategori tidak berpasangan. Dari perhitungan didapatkan hasil $n 1=n 2=38$. Jadi jumlah sampel masing-masing kelompok kasus dan kelompok kontrol adalah 38 orang sehingga jumlah sampel keseluruhan berjumlah 76 orang. Usia populasi sample dibatasi antara 40-60 tahun untuk mengurangi bias.

Pengumpulan data dilakukan dengan wawancara, pemeriksaan fisik, pemeriksaan laboratorium, ekokardiografi dan pemeriksaan kognitif, serta pengumpulan data sekunder (catatan medis RSUP Sanglah Denpasar). Nilai fraksi ejeksi ventrikel kiri berdasarkan kriteria dari Perhimpunan Dokter Spesialis Kardiovaskular Indonesia (PERKI). Adapun batasan nilai rendah dari fraksi ejeksi ventrikel kiri yang dipakai yaitu $<35 \%$.

Alat diagnostik yang digunakan untuk menunjang diagnostik suatu GFK yaitu dengan pemeriksaan MoCA-INA yang tercakup dalam instrumen pemeriksaan evaluasi neurobehavior/ status fungsi kortikal luhur (dewasa). Pemeriksaan status kognitif sebelumnya menggunakan kuesioner Short IQCODE dan pemeriksaan depresi menggunakan kuesioner Hamilton Rating Scale for Depression. Untuk penghitungan FEVK menggunakan ekokardiografi di RSUP Sanglah dengan merek GE VIVID 7, yang dilakukan oleh dokter IImu Penyakit Jantung.

Beberapa kriteria ekslusi pada penelitian ini yaitu: 1.Adanya anemia, fibrilasi atrial, riwayat stroke, cedera kepala, parkinson diabetes melitus, penyakit ginjal kronis, critical illness, paparan toksin, alkohol, rokok inflamasi, riwayat gangguan kognitif sebelumnya, riwayat gagal jantung eksaserbasi 3 bulan sebelumnya. 2.Adanya GFK sebelumnya yaitu bila nilai Short Form of the Informant Questionnaire on Cognitive Decline in the Elderly (Short IQCODE) $\geq 3,4$. 3.Penderita mengalami gangguan sistem imunitas tubuh seperti SLE, AIDS serta penyakit-penyakit lainnya (kecuali hipertensi yang mempengaruhi fungsi kognitif). 4.Adanya depresi berat.

Analisa statistik bivariat dilakukan dengan uj Chi-square, sedangkan analisis multivariat 
menggunakan regresi logistik. Analisa statistik dilakukan menggunakan komputer program SPSS versi 22.

\section{Hasil}

Penelitian ini melibatkan 76 orang subyek penderita GJS yang memenuhi kriteria eligibilitas, yang dikelompokkan sebagai kelompok FEVK dalam enam bulan yang menurun dan kelompok FEVK dalam enam bulan yang normal.

Hubungan antara penurunan FEVK sebagai variabel bebas, dan beberapa variabel lain sebagai perancu dengan GFK sebagai variabel tergantung pada penderita dengan GJS dinilai secara analisis bivariat menggunakan uji hipotesis Chi-square. Dari hasil uji statistik, ditemukan faktor yang berpengaruh adalah FEVK, pekerjaan, dan pendidikan. Analisis multivariat dilakukan dengan menggunakan analisa regresi logistik, dan didapatkan penurunan FEVK dalam enam bulan merupakan faktor risiko yang kuat, yang memiliki risiko mengalami gangguan kognitif pada penderita gagal jantung sistolik dengan adjusted $\mathrm{OR}=23,1$ setelah mengendalikan jenis kelamin, pendidikan dan pekerjaan

Tabel 1. Karakteristik Dasar Subjek Penelitian

\begin{tabular}{lcc}
\hline Karakteristik dasar & Kasus & Kontrol \\
\hline & $(\mathbf{n = 3 8 )}$ & $\mathbf{( n = 3 8 )}$ \\
\hline $\begin{array}{l}\text { Jenis Kelamin }(\mathrm{n}(\%)) \\
\quad \text { Laki-laki }\end{array}$ & $25(65,8)$ & $19(50,0)$ \\
$\quad$ Perempuan & $13(34,2)$ & $19(50,0)$ \\
Usia (tahun \pm SD) & & \\
$\quad$ Rerata \pm SD & $50,3 \pm 4,5$ & $51,5 \pm$ \\
& & 5,34 \\
$\quad$ Min-Maks & $40-58$ & $40-59$ \\
Pendidikan (n(\%)) & & \\
$\quad<12$ tahun & $32(84,2)$ & $4(10,5)$ \\
$\quad \geq 12$ tahun & $6(15,8)$ & $34(89,5)$ \\
Pekerjaan (n(\%)) & & \\
$\quad$ Formal & $23(60,5)$ & $13(34,2)$ \\
$\quad$ Informal & $15(39,5)$ & $25(65,8)$ \\
\hline
\end{tabular}

\section{Keterangan:}

Kasus : kelompok yang mengalami gangguan kognitif Kontrol : kelompok yang tidak mengalami gangguan kognitif

Tabel 1 menunjukan perbandingan subyek laki-laki dan perempuan relatif sama banyak. Usia subyek penelitian berkisar antara 40-59 tahun. Pendidikan tinggi lebih banyak pada kelompok kasus. Pekerjaan formal lebih banyak pada kelompok kasus.
Tabel 2. Analisis Bivariat GFK dengan Penurunan FEVK Dalam Enam Bulan

\begin{tabular}{lcccc}
\hline \multirow{2}{*}{ Variabel } & \multicolumn{2}{c}{ GFK } & \multirow{2}{*}{ OR } \\
\cline { 2 - 3 } & $\begin{array}{c}\text { Kasus } \\
\mathrm{n}(\%)\end{array}$ & $\begin{array}{c}\text { Kontrol } \\
\mathrm{n}(\%)\end{array}$ & \\
\hline IK 95\%)
\end{tabular}

${ }^{*}$ Bermakna secara statistik

Tabel 2 menunjukkan terdapat perbedaan kejadian GFK pada FEVK dalam enam bulan dengan penderita yang FEVK dalam enam bulan normal dengan nilai $\mathrm{OR}=56,1$ dan bermakna secara statistik

Tabel 3. Analisis Bivariat Variabel Lainnya dengan Penurunan Fungsi Kognitif

\begin{tabular}{|c|c|c|c|}
\hline & $\begin{array}{l}\text { Kasus } \\
n(\%)\end{array}$ & $\begin{array}{c}\text { Kontrol } \\
\text { n (\%) }\end{array}$ & $\begin{array}{c}\text { OR } \\
\text { (IK 95\%) }\end{array}$ \\
\hline \multicolumn{4}{|l|}{ Hipertensi } \\
\hline Terkontrol & $35(92,1)$ & $33(86,8)$ & 0,56 \\
\hline Tidak terkontrol & $3(7,9)$ & $5(13,2)$ & $\begin{array}{c}(0,12- \\
2,56) \\
P=0,71\end{array}$ \\
\hline \multicolumn{4}{|l|}{ Kelas NYHA } \\
\hline Terkontrol & 38 (100) & 38 (100) & \\
\hline Tidak terkontrol & $0(0)$ & $0(0)$ & NA \\
\hline \multicolumn{4}{|l|}{ Dislipidemia } \\
\hline Terkontrol & $35(92,1)$ & $32(84,2)$ & 0,45 \\
\hline $\begin{array}{l}\text { Tidak } \\
\text { terkontrol }\end{array}$ & $3(7,9)$ & $6(15,8)$ & $\begin{array}{c}(0,11- \\
1,98) \\
P=0.48\end{array}$ \\
\hline \multicolumn{4}{|l|}{ Pendidikan } \\
\hline $\begin{array}{l}<12 \text { tahun } \\
\geq 12 \text { tahun }\end{array}$ & $\begin{array}{c}32(84,2) \\
6(15,8)\end{array}$ & $\begin{array}{c}4(10,5) \\
34(89,5)\end{array}$ & $\begin{array}{c}45,3 \\
(11,7- \\
175,59) \\
P<0,001\end{array}$ \\
\hline \multicolumn{4}{|l|}{ Pekeriaan } \\
\hline $\begin{array}{l}\text { Formal } \\
\text { Informal }\end{array}$ & $\begin{array}{l}23(60,5) \\
15(39,5)\end{array}$ & $\begin{array}{l}13(34,2) \\
25(65,8)\end{array}$ & $\begin{array}{c}2,9 \\
(1,2-7,5) \\
P=0,02\end{array}$ \\
\hline
\end{tabular}

\section{Keterangan:}

NYHA: New York Heart Association NA: Not Available

Tabel 3 menunjukan ada 2 variable yang bermakna secara statistik, yang berhubungan dengan penurunan fungsi kognitif, yaitu pendidikan dan pekerjaan. 
Tabel 4. Analisis multivariat regresi logistik

\begin{tabular}{|c|c|c|}
\hline Karakteristik & $\begin{array}{l}\text { Ajusted } \\
\text { OR }\end{array}$ & IK 95\% \\
\hline \multicolumn{3}{|l|}{ Langkah 1} \\
\hline Penurunan EF & 24,2 & $\begin{array}{l}4,45-131,69 \\
P<0,001^{*}\end{array}$ \\
\hline Jenis kelamin laki-laki & 1,3 & $\begin{array}{l}0,23-7,27 \\
P=0,77\end{array}$ \\
\hline Pendidikan $<12$ th & 16,4 & $\begin{array}{l}3,18-84,18 \\
P=0,001^{*}\end{array}$ \\
\hline Pekerjaan formal & 3,0 & $\begin{array}{l}0,56-16,19 \\
P=0,20\end{array}$ \\
\hline \multicolumn{3}{|l|}{ Langkah 2} \\
\hline Penurunan EF & 24,95 & $\begin{array}{l}4,65-133,97 \\
P<0,001^{*}\end{array}$ \\
\hline Pendidikan $<12$ th & 16,20 & $\begin{array}{l}3,17-82,78 \\
P=0,001^{*}\end{array}$ \\
\hline Pekerjaan formal & 3,03 & $\begin{array}{l}0,57-16,19 \\
P=0,19\end{array}$ \\
\hline \multicolumn{3}{|l|}{ Langkah 3} \\
\hline Penurunan EF & 23,1 & $\begin{array}{l}4,7-114,03 \\
P<0,001^{*}\end{array}$ \\
\hline Pendidikan $<12$ th & 17,4 & $\begin{array}{l}3,5-87,1 \\
P=0,001\end{array}$ \\
\hline
\end{tabular}

Table 4 menunjukan penurunan FEVK dalam enam bulan merupakan faktor risiko yang kuat, yang memiliki risiko mengalami gangguan kognitif pada penderita gagal jantung sistolik dengan adjusted $\mathrm{OR}=23,1$ setelah mengendalikan jenis kelamin, pendidikan dan pekerjaan

\section{Pembahasan}

Prevalensi kejadian gagal jantung di Amerika, pada pria sebanding dengan wanita, yaitu $2 \%$ dari populasi berusia 25-74 tahun. Di Eropa, dilaporkan prevalensi kejadian GJS dengan FEVK kurang dari $30 \%$ adalah $4 \%$ pada pria, dan $2 \%$ pada wanita berusia 25-74 tahun. ${ }^{12}$ Pada usia di atas 65 tahun, terdapat peningkatan prevalensi GFK pada wanita, yang mungkin disebabkan oleh angka harapan hidup wanita yang lebih panjang dibanding pria. ${ }^{13}$

Pada penelitian yang dilakukan oleh peneliti didapatkan hasil yang bermakna antara tingkat pendidikan dengan GFK. Hal ini sesuai dengan penelitian-penelitian yang telah dilakukan sebelumnya dan sesuai dengan teori Cognitive Reserve (CR), di mana pada individu dengan tingkat pendidikan lebih lama ( $\geq 12$ tahun) memiliki lebih banyak kesempatan untuk berlatih dan belajar. Hal ini akan merangsang otak itu sendiri sehingga memiliki kapasitas neuron yang lebih baik dibandingkan individu yang pendidikannya $<12$ tahun. Teori Cognitive Reserve (CR) menyatakan bahwa individu yang mempunyai $\mathrm{CR}$ yang besar akan mempunyai kapasitas neuron yang lebih besar dan efisien, atau mempunyai proses kompensasi di dalam neural network apabila terjadi sebuah proses patologi di otak. CR yang besar ini bisa didapatkan melalui proses pengulangan stimulus kognitif dengan mekanisme meningkatnya kinerja mediator-mediator pada tingkat molekuler, seperti metilasi DNA, modifikasi histon, meningkatnya aktivitas dependent gene expression (neurotropin), meningkatnya jalur dan sintesa protein sehingga akan meningkatkan neurogenesis, plastisitas dari sinaps, gangliogenesis dan angiogenesis pada tingkat seluler, dengan hasil akhir meningkatnya plastisitas, kompensasi neuron, proses informasi, penyimpanan yang lebih efisien serta fungsi dan koneksi antar neuron yang meningkat pada tingkat sistemik. ${ }^{3}$

Resiko mengalami GFK pada penderita GJS pada subyek dengan penurunan FEVK dalam enam bulan adalah 56 kali dibandingkan pada subyek dengan FEVK dalam enam bulan tidak menurun dimana hasil ini bermakna secara statistik. Pada pasien geriatri terdapat korelasi GFK dengan penurunan FEVK dibawah $30 \%$ dengan 53\% Mini Mental State Examination (MMSE) kurang dari 24 terutama gangguan atensi. ${ }^{10}$ Penelitian lainnya terdapat perbedaan pendapat misalnya, pada studi Zuccala, peran FEVK diteliti pada usia dewasa tua dengan sampel kecil (rerata usia 76.6) yang menderita gagal jantung kronik (NYHA kelas III, FEVK 44\%) didapatkan hubungan tidak bermakna antara FEVK dan MMSE. ${ }^{9}$ Penelitian Festa et al. menganalisis 207 pasien dengan gagal jantung (rentang usia 17-72 tahun), didapatkan korelasi FEVK terhadap usia, yaitu kurang dari 63 tahun tidak ada penurunan fungsi memori terkait dengan FEVK, sedangkan pada usia lebih dari 63 tahun terdapat penurunan signifikan memori (terutama verbal delayed recall dan rekognisi) dengan FEVK $\leq 30 \%(P<0,02) .10$

Hurk et al. meneliti penderita gagal jantung yang dirawat jalan juga penderita gagal jantung dengan eksaserbasi yang dirawat (rerata usia 55-70 tahun dan variabel FEVK $25.7 \%$ dan 63\%), menemukan tidak ada hubungan antara fraksi ejeksi dan fungsi kognisi yang dinilai dengan tes global dan skala spesifik (Boston Naming Test, Trail Making Test Part B-Part A, Hooper Visual Organization Test) . ${ }^{11}$

Peneliti menemukan hasil yang berbeda dari penelitian sebelumnya, dimana peneliti mendapatkan adanya hubungan bermakna antara penurunan FEVK terhadap GFK. Hal ini dimungkinkan karena perbedaan definisi operasional dan ruang lingkup populasi sampel yang digunakan dalam penelitian ini. Gangguan fungsi jantung berkorelasi dengan terjadinya GFK. Faktor risiko gangguan fungsi jantung dinilai berdasarkan FEVK. Penurunan FEVK, maka semakin berat derajat gangguan fungsi jantung. Pada penderita GJS penurunan FEVK disertai juga dengan adanya kelainan pada pembuluh darah besar dan kecil yang menyebabkan kelainan pada subtansia alba serta berhubungan dengan gangguan pada fungsi kognitif. Aliran darah otak ditentukan oleh curah jantung. Disfungsi ventrikel kiri menyebabkan penurunan FEVK sehingga terjadi hipoperfusi serebral hipoksia dan iskemik. Hipoksia menyebabkan perubahan metabolik dan seluler. Perubahan metabolik dan seluler terdiri dari remodelling dan gangguan hemostasis kalsium. Hipoksia meningkatkan kalsium dan meregulasi fungsional saluran kalsium sehingga menyebabkan degenerasi aksonal dan kematian sel. Masuknya kalsium ke dalam neuron akan menginduksi stres oksidatif sehingga rentan terhadap excitotoxicity dan apoptosis. ${ }^{14}$

Studi meta-analisis oleh $\mathrm{Xu}$ et al. tentang pengaruh obat antihipertensi terhadap fungsi kognitif, ditemukan bahwa obat antihipertensi dapat menurunkan angka insiden demensia. ${ }^{15}$ Pada penelitian prospektif Haring et al. pada subyek 6.426 
wanita berusia 65-79 tahun dalam Women's Memory Initiative Memory Study, yang diikuti 9,1 tahun, hipertensi meningkatkan risiko GFK sebesar $20 \%$. Wanita dengan tekanan darah lebih dari $140 / 90 \mathrm{mmHg}$ memiliki $30 \%$ peningkatan risiko GFK. ${ }^{16}$ Pada penelitian ini, pasien yang berobat ke poli jantung RSUP Sanglah mendapatkan obat antihipertensi setiap bulannya, sehingga pasien memiliki tekanan darah yang terkontrol.

Pada studi Athilingam et al., NYHA sebagai prediktor yang baik untuk menentukan fungsi kognitif sebagai faktor risiko gagal jantung. ${ }^{17}$ Leto dan Feola menemukan pada 44 penderita gagal jantung rawat jalan $>65$ tahun, $52 \%$ pasien dengan NYHA III dan IV dengan usia rerata 76 tahun dan rerata FEVK 37\%, didapatkan $70 \%$ subyek mengalami GFK yang dinilai dengan $\mathrm{MoCA}<26 .{ }^{6}$ Dengan pemeriksaan single photon emission computed tomography (SPECT), terlihat adanya penurunan aliran darah cerebral sekitar $30 \%$ pada pasien dengan NYHA kelas III/IV. ${ }^{17}$ Pada penelitian ini pasien yang menjalani perawatan ke poli kardiologi telah mengalami perbaikan kelas NYHA, sehingga hampir $100 \%$ pasien datang dengan kelas NYHA I. Hal ini menyebabkan kelas NYHA tidak dapat dianalisis sebagai faktor resiko GFK pada penderita gagal jantung.

Pada penelitian Zhao et al. terhadap suatu populasi di China, menemukan tidak ada perbedaan angka kejadian gangguan fungsi kognitif signifikan antara grup dislipidemia dan grup dengan kadar lipid normal. ${ }^{19}$ Pada studi meta-analisis kolesterol sebagai faktor risiko demensia dan GFK pada 14.331 penderita demensia Alzheimer, didapatkan 9.458 penderita dengan demensia vaskular, 1.893 mengalami penurunan fungsi kognitif, dan 4793 penderita dengan GFK. ${ }^{20}$ Pada penelitian Cheng et al. korelasi antara kolesterol dan fungsi kognitif didapatkan subyek dengan kadar kolesterol 154.6-186.7 mg/dL mempunyai fungsi kognitif terbaik. Sedangkan studi penelitian lainnya di negara maju, pasien dengan kadar kolesterol tinggi yang diobati dengan obat penurun lipid, terbukti berpotensi melindungi risiko GFK. ${ }^{21}$ Pada penelitian ini, pasien yang berobat ke poli jantung RSUP Sanglah mendapatkan obat penurun lipid setiap bulannya, sehingga pasien memiliki kadar lipid yang terkontrol.

Pada analisis multivariat didapatkan penurunan FEVK dalam enam bulan merupakan faktor risiko yang kuat memiliki risiko mengalami gangguan kognitif pada penderita gagal jantung sistolik dengan adjusted $\mathrm{OR}=23,1$ setelah mengendalikan jenis kelamin, pendidikan dan pekerjaan $(\mathrm{OR}=23,1$; IK $95 \% 4,7-114,03 ; p<0,001)$

\section{Simpulan}

Dari penelitian ini dapat disimpulkan, terjadi peningkatan risiko GFK sebesar dua puluh tiga kali yang bermakna secara statistik pada penderita GJS dengan penurunan FEVK dalam 6 bulan, di Rumah Sakit Umum Pusat Sanglah.

\section{Saran}

Penulis menyarankan agar dilakukan pemeriksaan fungsi kognitif pada penderita GJS dengan penurunan FEVK secara rutin. Selain itu juga diperlukan penelitian kerjasama lanjutan antara bagian neurologi dan kardiologi untuk mendeteksi sejak dini GFK pada penderita GJS dengan penurunan FEVK.

\section{Ucapan terima kasih}

Pada kesempatan ini penulis ingin menyampaikan ucapan terima kasih kepada seluruh pasien serta anggota keluarga pasien yang telah berkenan menjadi subjek penelitian, dan bagian Kardiologi RSUP Sanglah yang telah memfasilitasi penelitian ini.

\section{Daftar Pustaka}

1. Ampadu J, Morley JE. Heart failure and cognitive dysfunction. International Journal of Cardiology. 2015;178:12-23.

2. Vogels RLC, Scheltens P. Cognitive impairment in heart failure: a systematic review of the literature. Eur $J$ Heart Fail. 2007;9:440-449.

3. Miller LA, Spitznagel MB, Alosco M. Cognitive profiles in heart failure: a cluster analytic approach. $J$ Clin Exp Neuropsychol. 2012;34:509-520.

4. Tilvis RS, Ka"ho"nen-Va"re MH, Jolkkonen J. Predictors of cognitive decline and mortality of aged people over a 10-year period. J Gerontol A Biol Sci Med Sci. 2004;59(3):268-274.

5. Mosterd A, Hoes AW. Clinical epidemiology of heart failure. Heart. 2007;93:1137-1146.

6. Leto L, Feola M. Cognitive impairment in heart failure patients. Journal of Geriatric Cardiology. 2014;11:316-328.

7. Cermakova $P$, Lund LH, Fereshtehnejad SM, Johnell K, Winblad B, Dahlstrom U, et.al. Heart failure and dementia: survival in relation to types of heart failure and different dementia disorders. European Journal of Heart Failure. 2015;17:612-619.

8. Hoth KF, Poppas A, Ellison KE. Link between change in cognition and left ventricular function following cardiac resynchronization therapy. Journal of Cardiopulmonary Rehabilitation and Prevention. 2010;30( 6):401-408.

9. Zuccalà G, Cattel C, Gravina EM. Left ventricular dysfunction: a clue to cognitive impairment in older patients with heart failure. Journal of Neurology, Neurosurgery, and Psychiatry. 2007;63:509-512.

10. Festa JR, Jia X, Cheung K. Association of low ejection fraction with impaired verbal memory in older patients with heart failure, Archives of Neurology, 2011;(68)8:1021-1026.

11. Hurk K, Reijmer YD, Ven den berg E. Heart failure and cognitive function in the general population: the Hoorn Study. Eur J Heart Fail. 2011;13:1362-1369.

12. Metha PA, Cowie MR. Gender and heart failure: a population perspective. Heart. 2006; 92(suppl 3): iii14iii 18.

13. Hugo J, Ganguli M. Dementia and cognitive impairment: epidemiology, diagnosis, and treatment.Clin Geriatr Med, 2014;30(3):421-42.

14. Jefferson AL, Himali JJ, Au R, Seshadri S, DeCharli C, et.al. Relation of Left Ventricular Ejection Fraction to Cognitive Aging (from the Framingham Heart Study). Am J Cardiol. 2011;108:1346-1351

15. Xu G, Bai F, Lin X, Wang Q, Wu Q, Sun S, et.al. Association between Antihypertensive Drug Use and the Incidence of Cognitive Decline and Dementia: A Meta-Analysis of Prospective Cohort Studies. BioMed Research International. 2017, Article ID 4368474. 
16. Haring B, Wu C, Coker LH, Seth A, Snetselaar L, Manson JAE, Rossouw JE, et.al.Hypertension, Dietary Sodium, and Cognitive Decline: Results From the Women's Health Initiative Memory Study. Am J Hypertens. 2016;29(2):202-216.

17. Athilingam $P$, D'aoust $R$, Zambroski $C$, McMillan SC, Sahebzemani F. Predictive Validity of NYHA and ACC/AHA Classifications of Physical and Cognitive Functioning in Heart Failure. International Journal of Nursing Science. 2013;3(1):22-32.

18. Dardiotis E, Giamouzis G, Mastrogiannis D, Vogiatzi C, Skoularigis J, Triposkiadis F, et.al. Cognitive impairment in heart failure. Cardiology Research and Practice. 2012, Article ID 595821.
19. Zhao B, Shang S, Li P, Chen C, Dang L, Jiang Y, et.al. The gender and age dependent relationships between serum lipids and cognitive impairment: a cross-sectional study in a rural area of Xi'an, China. Lipids in Health and Disease. 2019;18:4.

20. Ansley KJ, Lipnicki DM, Low LF. Cholesterol as a risk factor for dementia and cognitive decline: a systematic review of prospective studies with metaanalysis.Am J Geriatr Psychiatry. 2008;16(5):343-54.

21. Cheng Y, Jin Y, Unverzagt FW, Su L, Yang L, Ma $F$, et.al. The relationship between cholesterol and cognitive function is homocysteine-dependent. Clin Interv Aging. 2014;23;9:1823-9. 